\title{
Stability of Cry1 Ab protein during long-term storage for standardization of insect bioassays
}

\author{
Hang Thu NGUYEN and Johannes A. JEHLE* \\ Agricultural Service Center Palatinate (DLR Rheinpfalz), Department of Phytopathology, Laboratory for Biotechnological Crop Protection, \\ Breitenweg 71, 67435 Neustadt an der Weinstrasse, Germany
}

\begin{abstract}
The reliable use of purified Cry1Ab protein standards is a prerequisite for ecological studies and resistance monitoring programs of Cry1Ab-expressing transgenic corn. In this study the stability and activity of different Cry $1 \mathrm{Ab}$ protein batches expressed in and purified from Escherichia coli were determined during two-year storage at different temperature conditions $\left(4^{\circ} \mathrm{C},-20^{\circ} \mathrm{C}\right.$, and $\left.-80^{\circ} \mathrm{C}\right)$. SDS-Polyacrylamide gel electrophoresis showed degradation of the protein stored at $4{ }^{\circ} \mathrm{C}$ over four months, whereas no difference in the band intensity of the Cry $1 \mathrm{Ab}$ proteins stored at $-20{ }^{\circ} \mathrm{C}$ and $-80^{\circ} \mathrm{C}$ was observed. Bioassays with neonate larvae of Ostrinia nubilalis indicated that the biological activity of Cry1 Ab varied from batch to batch, depending on the production process. Cry $1 \mathrm{Ab}$ protein stored at $4{ }^{\circ} \mathrm{C}$ for four months showed a significantly decreasing activity measured as median lethal concentration ( $\mathrm{LC}_{50}$ ), whereas the protein activity declined less than 11-fold after two years storage at $-20{ }^{\circ} \mathrm{C}$. When stored at $-80{ }^{\circ} \mathrm{C}$ the toxin activity remained relatively stable for at least 30 months, as indicated by low $\mathrm{LC}_{50}$ values of 7-10 $\mathrm{ng}$ Cry1 Ab per $\mathrm{cm}^{2}$ diet. These experiments demonstrate that appropriate long-term storage conditions of Cry1Ab protein standards are crucial for resistance monitoring programs of $B t$ corn, and storage at $-80^{\circ} \mathrm{C}$ is recommended.
\end{abstract}

Keywords: Bt corn / Ostrinia nubilalis / resistance monitoring / bioassay

\section{INTRODUCTION}

Since the 1990s, transgenic crops expressing different Cry proteins of Bacillus thuringiensis (Bt) have become a new approach for insect pest control in agriculture. Cry $1 \mathrm{Ab}$ is the primary protein used in $B t$ corn to protect the crop from damage by lepidopteran insect pests, particularly the European corn borer (ECB), Ostrinia nubilalis (Hübner). In 2006, different varieties of $B t$ corn were planted on more than 23.9 million hectares worldwide (Brookes and Barfoot, 2008). However, the evolution of resistance of target pest populations to transgenically expressed Cry1 Ab is considered as a severe drawback of this new control strategy. In laboratory experiments using ECB populations it was demonstrated that the Cry1 Ab susceptibility significantly decreased after only seven generations when selected with commercial Bt formulations (Huang et al., 1997). Field monitoring data in transgenic cotton revealed resistance of some field populations of Helicoverpa zea to Cry1Ac protein, though field-evolved resistance in other five major lepidopteran pests (O. nubilalis, Sesamia nonagrioides, $H$. armigera, Heliothis virescens, Pectinophora gossypiella)

*Corresponding author: johannes.jehle@dlr.rlp.de could not be demonstrated (Tabashnik et al., 2008). Hence, effective insect resistance management strategies appear to be essential to retain the efficacy of $B t$ crops. The development of reliable insect resistance monitoring methods allowing early detection of changes of the susceptibility of target insects are an important cornerstone of any resistance monitoring scheme (EPA, 1998; Gould, 1998). For Bt corn, the Cry 1 Ab susceptibilities of ECB field populations have been monitored in different countries, e.g. the US, Spain, France, Germany and others (Chaufaux et al., 2001; Gonzáles-Núñez et al., 2000; Marçon et al., 1999; Martens et al., 1995; Saeglitz et al., 2006; Siegfried et al., 1995). Field studies on two ECB populations in Spain did not reveal any difference in their Cry1Ab susceptibilities (Gonzáles-Núñez et al., 2000), whereas small variations in susceptibility to Cry1 Ab protein among different geographical ECB populations were observed in the USA and in Germany (Marçon et al., 1999; Saeglitz et al., 2006). These variations, however, could be caused by (i) an existing natural variability among geographical populations; (ii) by different activities of Cry $1 \mathrm{Ab}$ proteins used in the different tests; or (iii) by an intrinsic variability of different bioassays when using the same insect colony and the same Cry1 Ab protein batch (Farinós et al., 2004; Marçon et al., 2000; Meise 
Table 1. Production and storage parameters of different Cry1 Ab batches.

\begin{tabular}{|c|c|c|c|c|c|c|}
\hline Cry1Ab-batch & $\begin{array}{c}\text { Protein amount } \\
(\mathrm{mg})\end{array}$ & $\begin{array}{l}\text { Concentration } \\
\text { at starting point } \\
\quad\left(\mathrm{mg} \cdot \mathrm{mL}^{-1}\right)\end{array}$ & $\begin{array}{c}\text { Concentration after } \\
\text { two years storage } \\
\left(\mathrm{mg} \cdot \mathrm{mL}^{-1}\right),(\mathrm{SD}) n=10\end{array}$ & $\begin{array}{c}\text { Purity } \\
(\%)\end{array}$ & Treatment & $\begin{array}{c}\text { Storage } \\
\text { temperature }\end{array}$ \\
\hline J6B & 18 & 1.3 & n.d. & 80 & $1 \times \mathrm{T}$ & $4{ }^{\circ} \mathrm{C}$ \\
\hline $\mathrm{H} 3$ & 243 & 1.0 & $1.0(0.15)$ & 93 & $2 \times \mathrm{T}, \mathrm{UF}$ & $-20^{\circ} \mathrm{C},-80^{\circ} \mathrm{C}$ \\
\hline $\mathrm{H} 4$ & 200 & 0.8 & $0.8(0.15)$ & 84 & $1 \times \mathrm{T}, \mathrm{UF}$ & $-20^{\circ} \mathrm{C},-80^{\circ} \mathrm{C}$ \\
\hline
\end{tabular}

$\mathrm{SD}=$ standard deviation, n.d.: not determined due to protein precipitation, T: trypsinization, UF: ultrafiltration.

and Langenbruch, 2007; Nguyen et al., 2004; Saeglitz et al., 2006). Hence, the standardization of the bioassay methodology as well as the application of standardized $\mathrm{Cry} 1 \mathrm{Ab}$ proteins is of greatest importance in order to obtain meaningful data. Recently, different standardized methods for quantifying Cry $1 \mathrm{Ab}$ protein from independent sources were compared and validated (Crespo et al., 2008). It was concluded that standardization of production and quantification of Cry $1 \mathrm{Ab}$ batches may improve data consistency in monitoring efforts, and will be essential for the identification of changes of the susceptibility of target pests to Cry $1 \mathrm{Ab}$ protein.

In our study we addressed the question how long a defined $\mathrm{Cry} 1 \mathrm{Ab}$ protein standard keeps its bioactivity and what are the best storage conditions. Here, we present the results of storage experiments of different Cry $1 \mathrm{Ab}$ batches, which were evaluated for their biochemical and biological stability during two year storage at different temperatures.

\section{RESULTS}

\section{Production and stability of Cry1Ab protein batches}

The production parameters of three trypsinized Cry1 $\mathrm{Ab}$ batches J6B, H3 and $\mathrm{H} 4$, including protein concentration, purity, treatment during production and storage temperature are listed in Table 1. Batch J6B was stored for four months at $4{ }^{\circ} \mathrm{C}$, whereas the batches $\mathrm{H} 3$ and $\mathrm{H} 4$ were stored for 24 months in duplicate at $-20^{\circ} \mathrm{C}$ and $-80^{\circ} \mathrm{C}$. To compare the protein concentration before and after storage, Bradford dye assay was conducted. No decrease in the concentration of batches $\mathrm{H} 3$ and $\mathrm{H} 4$ was observed after two years storage at $-20{ }^{\circ} \mathrm{C}$ (Tab. 1). Their protein concentration was still 1.0 and $0.8 \mathrm{mg} . \mathrm{mL}^{-1}$, respectively. In contrast, batch J6B was not measurable after 16 weeks storage due to protein precipitation.

The quality and stability of batch J6B was examined by SDS polyacrylamide gel electrophoresis (PAGE). After one week a minor band of 67 and a major band of $60 \mathrm{kDa}$ were visible (Fig. 1). After 1.5-4 months the $67 \mathrm{kDa}$ protein band had disappeared and two bands of

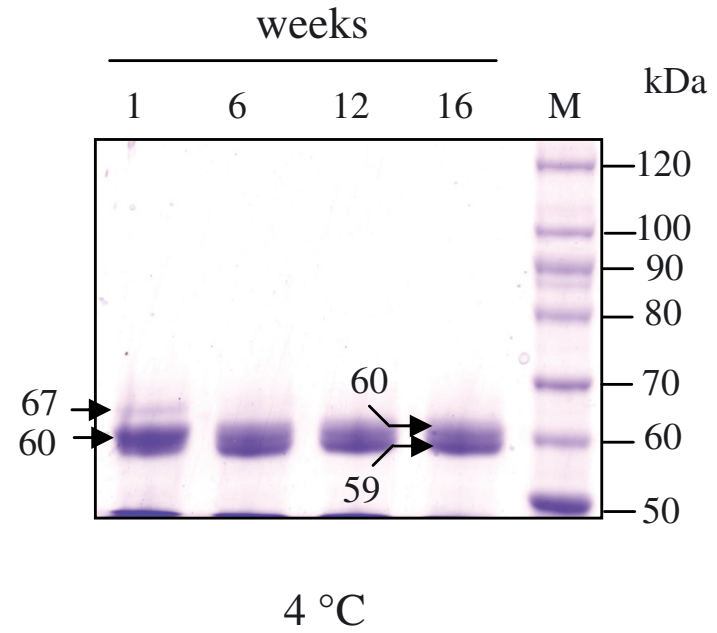

Figure 1. SDS polyacrylamide gel electrophoresis (7\% gel) of Cry1 Ab batch J6B after 1-, 6-, 12- and 16-week storage at $4{ }^{\circ} \mathrm{C}$. $\left(\mathrm{M}=\right.$ BenchMark $^{\mathrm{TM}}$ protein ladder (GibcoBRL) with molecular masses ( $\mathrm{kDa}$ ) given to the right.)

60 and $59 \mathrm{kDa}$ were observed. Due to rapid degradation of batch J6B at $4{ }^{\circ} \mathrm{C}$, the other batches $\mathrm{H} 3$ and $\mathrm{H} 4$ were stored at $-20{ }^{\circ} \mathrm{C}$ and $-80{ }^{\circ} \mathrm{C}$ and their stability was examined.

Trypsinization of $130 \mathrm{kDa}$ Cry $1 \mathrm{Ab}$ protoxin of batch $\mathrm{H} 3$ resulted in three different bands with a molecular weight of 70, 67 and $60 \mathrm{kDa}$ (Fig. 2, lane 2). Since it was assumed that the 70 and $67 \mathrm{kDa}$ bands were due to incomplete trypsinization, a second trypsinization was performed. By adjusting the $\mathrm{pH}$ of the protein solution to 9.5 and repeating trypsinization at $22{ }^{\circ} \mathrm{C}$ overnight, a single Cry $1 \mathrm{Ab}$ protein band of $60 \mathrm{kDa}$ was obtained (Fig. 2, lane 3). Trypsinization of the batch H4 immediately resulted in a single $60 \mathrm{kDa}$ band (Fig. 2, lane 4).

Batches $\mathrm{H} 3$, and $\mathrm{H} 4$ were stored for 24 months at $-20^{\circ} \mathrm{C}$ and $-80^{\circ} \mathrm{C}$ and aliquots were sampled after 6,12 , and 24 months. As shown in Figure 3, no change in number and intensity of the Cry1 Ab band of batch $\mathrm{H} 3$ was observed at both storage temperatures. The same result 

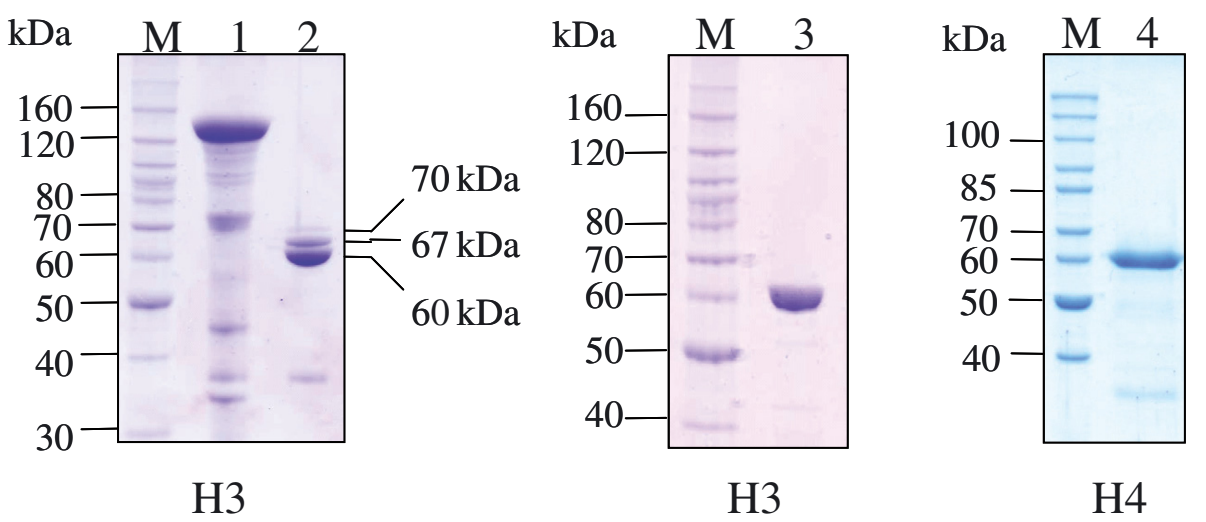

Figure 2. SDS polyacrylamide gel electrophoresis (7-10\% gel) of Cry1 Ab batches $\mathrm{H} 3$ and $\mathrm{H} 4$ after production and trypsinization. (Lane 1 = batch H3 full-length Cry1 Ab protoxin $130 \mathrm{kDa}$, lane $2=$ batch $\mathrm{H} 3(1 \times$ trypsinized), lane $3=$ batch $\mathrm{H} 3(2 \times$ trypsinized), lane 4 = batch $\mathrm{H} 4, \mathrm{M}=$ PageRuler $^{\mathrm{TM}}$ protein ladder (Fermentas) with molecular masses (kDa) given to the left.)

was obtained for the batch $\mathrm{H} 4$, indicating that storage at $-20{ }^{\circ} \mathrm{C}$ or lower rendered stable Cry $1 \mathrm{Ab}$ samples.

\section{Stability of the biological activity of Cry1 Ab batches}

Bioassays with Cry1 Ab batch J6B, which was stored at $4{ }^{\circ} \mathrm{C}$, were performed from one week to four months after production (Tab. 2). The $\mathrm{LC}_{50}$ dramatically increased from $77 \mathrm{ng} . \mathrm{cm}^{-2}$ (1 week) to $1717 \mathrm{ng} . \mathrm{cm}^{-2}$ (6 weeks) and 1243 ng.cm ${ }^{-2}$ (4 months), indicating a significant reduction of the insecticidal activity of this batch.

Due to the lack of larvae at the beginning of the storage experiment of batch $\mathrm{H} 3$, the first determination of its bioactivity was performed after 5 months storage at $-20{ }^{\circ} \mathrm{C}\left(\mathrm{LC}_{50}=240 \mathrm{ng}\right.$ Cry $1 \mathrm{Ab} . \mathrm{cm}^{-2}$ diet $)$ and 10 months storage at $-80{ }^{\circ} \mathrm{C}\left(\mathrm{LC}_{50}=54 \mathrm{ng}\right.$ Cry $1 \mathrm{Ab} . \mathrm{cm}^{-2}$ diet) (Tab. 2). Compared to the $\mathrm{LC}_{50}$ values of the batch $\mathrm{H} 4$ at comparable storage periods, the bioactivity of the double-trypsinized batch $\mathrm{H} 3$ appeared to be consistently lower. At $-20{ }^{\circ} \mathrm{C}$ storage the $\mathrm{LC}_{50}$ values steadily increased until 25 months $\left(\mathrm{LC}_{50}=1931 \mathrm{ng}\right.$ Cry $1 \mathrm{Ab} . \mathrm{cm}^{-2}$ diet). After 25 months storage at $-80{ }^{\circ} \mathrm{C}$ the $\mathrm{LC}_{50}$ value slightly increased $\left(\mathrm{LC}_{50}=165 \mathrm{ng}\right.$ Cry $1 \mathrm{Ab} . \mathrm{cm}^{-2}$ diet $)$ compared to 15 months before (Tab. 2). Bioassays with batch $\mathrm{H} 4$ performed after 7 months storage at $-20^{\circ} \mathrm{C}$ and $-80{ }^{\circ} \mathrm{C}$ gave similar $\mathrm{LC}_{50}$ values of $3 \mathrm{ng}$ Cry $1 \mathrm{Ab} . \mathrm{cm}^{-2}$ and $2 \mathrm{ng}$ Cry $1 \mathrm{Ab} . \mathrm{cm}^{-2}$ diet, respectively (Tab. 2). Until month 22, an 11-fold activity decrease could be observed at $-20{ }^{\circ} \mathrm{C}$ storage, whereas no statistically significant difference was observed between the $\mathrm{LC}_{50}$ values after 7 and 13 months, and after 13 and 22 months storage at $-80{ }^{\circ} \mathrm{C}$. The results obtained with batches $\mathrm{H} 3$ and $\mathrm{H} 4$ indicated that the bioactivity of $\mathrm{Cry} 1 \mathrm{Ab}$ remained more stable when stored at $-80{ }^{\circ} \mathrm{C}$ compared to $-20{ }^{\circ} \mathrm{C}$.

\section{DISCUSSION}

The objective of this study was to investigate the stability of the purified Cry $1 \mathrm{Ab}$ protein during long-term storage at different temperature conditions. Biochemical and biological methods were applied to control the quality of three different Cry1 Ab protein batches JB6, H3, and H4. Bradford dye assays provided information about the total protein concentration of each batch after purification and demonstrated a stable concentration of Cry $1 \mathrm{Ab}$ protein during long-term storage. The total protein concentration of Cry $1 \mathrm{Ab}$ protein in different batches did not change after two years of storage at $-20{ }^{\circ} \mathrm{C}$ (Tab. 1). Crespo et al. (2008) compared SDS-PAGE, ELISA and Bradford assays for estimating Cry $1 \mathrm{Ab}$ concentrations in production batches and found that Bradford assays had the lowest coefficient of variation. However, this method did not allow determining whether a Cry $1 \mathrm{Ab}$ protein in a production batch is really stable or degraded, because it is not possible to differentiate between active Cry $1 \mathrm{Ab}$ proteins and its degradation products.

By SDS-PAGE, the molecular weight and the purity of Cry1 Ab protein can be determined. SDS PAGE analysis of protein batch J6B during storage at $4{ }^{\circ} \mathrm{C}$ allowed identifying the transition of this protein from $67 \mathrm{kDa}$ and $60 \mathrm{kDa}$ to $59 \mathrm{kDa}$ (Fig. 2). This degradation could be the result of further proteolysis by the residual activities of trypsin, as it was not removed from the protein solution during production of batch J6B. Based on this result, the two other Cry $1 \mathrm{Ab}$ batches $\mathrm{H} 3$ and $\mathrm{H} 4$ were ultra-filtrated and stored at $-20^{\circ} \mathrm{C}$ and $-80^{\circ} \mathrm{C}$. SDS PAGE analyses did not show any degradation of these proteins during two years storage at both temperatures (Fig. 3). Thus, removing of trypsin by ultra-filtration and freezing kept Cry $1 \mathrm{Ab}$ protein batches stable, without changing their biochemical properties. 
Table 2. Bioactivity (median lethal concentration, $\mathrm{LC}_{50}$ ) of Cry $1 \mathrm{Ab}$ batch $\mathrm{J} 6 \mathrm{~B}, \mathrm{H} 3$ and $\mathrm{H} 4$ during storage at $4{ }^{\circ} \mathrm{C},-20^{\circ} \mathrm{C}$ and $-80{ }^{\circ} \mathrm{C}$.

\begin{tabular}{|c|c|c|c|c|c|c|c|}
\hline Batch & Storage temperature & Storage time (months) & $N$ & $\mathrm{LC}_{50}(\mathrm{FL})^{*}\left[\right.$ ng Cry $1 \mathrm{Ab} . \mathrm{cm}^{-2}$ diet $]$ & Slope \pm SE & $\chi^{2}$ & $\mathrm{p}^{* *}$ \\
\hline \multirow[t]{6}{*}{ J6B } & $4^{\circ} \mathrm{C}$ & 0.25 & 63 & $77(46-121)^{\mathrm{a}}$ & $1.0 \pm 0.22$ & 8.4 & 1 \\
\hline & & 0.5 & 221 & $111(57-200)^{\mathrm{a}}$ & $0.45 \pm 0.08$ & 1.3 & 0.69 \\
\hline & & 0.75 & 256 & $300(150-630)^{\mathrm{b}}$ & $0.36 \pm 0.07$ & 3.7 & 0.26 \\
\hline & & 1 & 383 & $541(200-1800)^{\mathrm{bc}}$ & $0.57 \pm 0.13$ & 8.8 & 0.14 \\
\hline & & 1.5 & 256 & $1700(970-5400)^{\mathrm{c}}$ & $0.61 \pm 0.18$ & 1.4 & 0.05 \\
\hline & & 4 & 256 & $1200(680-3300)^{\mathrm{c}}$ & $0.44 \pm 0.09$ & 0.4 & 0.06 \\
\hline \multirow[t]{7}{*}{$\mathrm{H} 3$} & $-20^{\circ} \mathrm{C}$ & 5 & 484 & $240(60-1200)^{\mathrm{a}}$ & $1.3 \pm 0.29$ & 16.4 & 1 \\
\hline & & 10 & 629 & $960(470-2000)^{\mathrm{ab}}$ & $1.2 \pm 0.17$ & 16.7 & 0.25 \\
\hline & & 19 & 637 & $1700(410-20000)^{\mathrm{b}}$ & $1.6 \pm 0.45$ & 28.3 & 0.14 \\
\hline & & 25 & 639 & $1900(1400-2600)^{\mathrm{b}}$ & $1.2 \pm 0.10$ & 5.9 & 0.13 \\
\hline & $-80^{\circ} \mathrm{C}$ & 10 & 768 & $54(30-95)^{\mathrm{a}}$ & $1.6 \pm 0.21$ & 14.6 & 1 \\
\hline & & 19 & 756 & $63(20-159)^{\mathrm{ab}}$ & $1.3 \pm 0.24$ & 32.0 & 0.86 \\
\hline & & 25 & 630 & $165(94-293)^{b}$ & $1.7 \pm 0.23$ & 13.4 & 0.33 \\
\hline \multirow[t]{6}{*}{$\mathrm{H} 4$} & $-20^{\circ} \mathrm{C}$ & 7 & 768 & $3(2-4)^{\mathrm{a}}$ & $1.8 \pm 0.21$ & 1.4 & 1 \\
\hline & & 13 & 511 & $4(3-6)^{\mathrm{a}}$ & $1.2 \pm 0.11$ & 1.2 & 0.75 \\
\hline & & 22 & 635 & $33(19-65)^{\mathrm{b}}$ & $1.4 \pm 0.19$ & 11.2 & 0.10 \\
\hline & $-80^{\circ} \mathrm{C}$ & 7 & 767 & $2(0-5)^{\mathrm{a}}$ & $0.94 \pm 0.21$ & 14.0 & 1 \\
\hline & & 13 & 637 & $6(2-14)^{\mathrm{ab}}$ & $0.99 \pm 0.17$ & 12.2 & 0.33 \\
\hline & & 22 & 632 & $7(4-11)^{\mathrm{b}}$ & $1.2 \pm 0.14$ & 8.7 & 0.28 \\
\hline
\end{tabular}

* $\mathrm{LC}_{50}$ values followed by the same letters within each batch of Cry1 Ab protein were not statistically different $(\alpha \leqslant 0.05 ;$ Smith, 1997).

** p: Potency of $\mathrm{LC}_{50}$ from the first storage time point (T1) relative to that of $\mathrm{LC}_{50}$ from the same batch after $n$ months storage (Tn) is estimated as: $\mathrm{p}_{n}=\mathrm{LC}_{50(\mathrm{~T} 1)} / \mathrm{LC}_{50(\mathrm{~T} n)} . N$ : number of tested larvae, $\mathrm{FL}=95 \%$ fiducial limits, $\mathrm{SE}=$ standard error, $\chi^{2}: \mathrm{Chi}^{2}$.

Bioassays clearly demonstrated that different temperature conditions and storage periods can affect the biological stability of Cry $1 \mathrm{Ab}$ protein. Activity of protein batch J6B significantly decreased 16 -fold during one week to four months storage at $4{ }^{\circ} \mathrm{C}$. This could be caused by further proteolysis of a partly incorrectly refolded protein with remaining trypsin after trypsinization of Cry1 $\mathrm{Ab}$ protein, and is consistent with the SDS-PAGE analysis, which showed the degradation of a part of this protein from 60 to $59 \mathrm{kDa}$ at $4{ }^{\circ} \mathrm{C}$. The loss of activity of Cry $1 \mathrm{Ab}$ protein was also observed by Höfte et al. (1986) and Martens et al. (1995) when a few amino acids from either the $\mathrm{N}$-terminus or the $\mathrm{C}$-terminus of the Cry $1 \mathrm{Ab}$ trypsin-resistant core were removed. The potential impact of residual trypsin activity on batch J6B is further supported by a previous study, when no significant difference in the activity of an ultra-filtrated Cry $1 \mathrm{Ab}$ protein batch could be observed during 4.5 months of storage at $4{ }^{\circ} \mathrm{C}$ (Nguyen et al., 2004).

The bioactivity of the Cry1 $\mathrm{Ab}$ batches $\mathrm{H} 3$ and $\mathrm{H} 4$ decreased significantly by a factor of 8 to 11 -fold when stored at $-20^{\circ} \mathrm{C}$ for two years (Tab. 2). In contrast, when stored at $-80{ }^{\circ} \mathrm{C}$ they remained relatively stable during the same period of time. The observed difference in $\mathrm{LC}_{50}$ values was up to 3.5 -fold. This could be caused by the variability in the response of the larvae and not by a decline of Cry1 Ab bioactivity. An up to 3-fold variability of the $\mathrm{LC}_{50}$ was observed when the same Cry $1 \mathrm{Ab}$ batch had been used in repeated bioassays during one week (Nguyen et al., 2004).

The outcome of the bioassays clearly indicated that long-term storage of Cry $1 \mathrm{Ab}$ protein at $-80{ }^{\circ} \mathrm{C}$ can preserve the bioactivity better than storage at $4{ }^{\circ} \mathrm{C}$ and $-20{ }^{\circ} \mathrm{C}$. The reason why both $\mathrm{Cry} 1 \mathrm{Ab}$ batches $\mathrm{H} 3$ and $\mathrm{H} 4$ lost some of their bioactivity during storage at $-20^{\circ} \mathrm{C}$ but remained stable at $-80^{\circ} \mathrm{C}$ is not fully clear. Normally, the protein must fold into compact structures with few exposed loops, in order to avoid excessive proteolysis in the insect gut (Bosch et al., 1994). We assume that storage at $-20{ }^{\circ} \mathrm{C}$ and at $-80{ }^{\circ} \mathrm{C}$ caused slightly differing folding structures of Cry $1 \mathrm{Ab}$ proteins, which could not be detected by SDS-PAGE and Bradford assay but may have increased the susceptibility of Cry $1 \mathrm{Ab}$ to protease digestion in the insect gut and thus resulted in a decreased activity in the bioassay. A considerable variation in the bioactivity of the two Cry $1 \mathrm{Ab}$ batches $\mathrm{H} 3$ and $\mathrm{H} 4$ was observed. This is in agreement with previous studies, where different Cry $1 \mathrm{Ab}$ sources resulted in a four- to eight-fold 


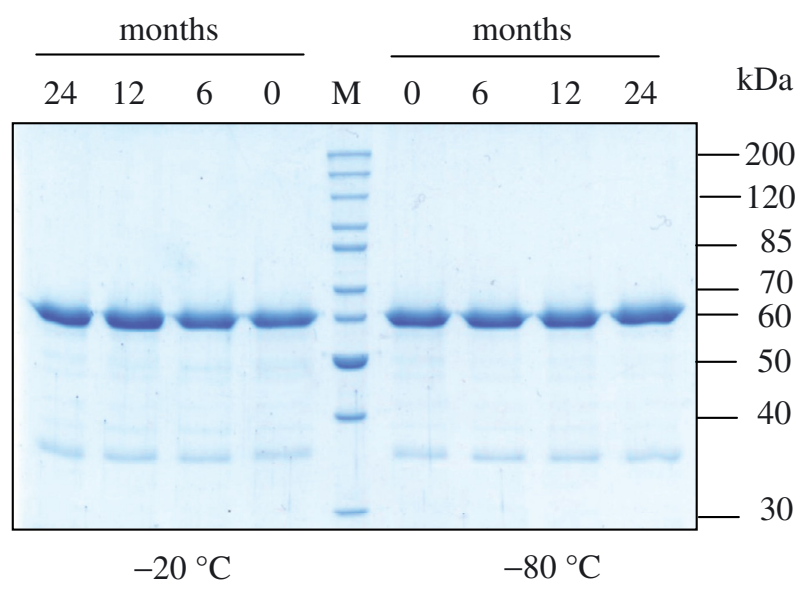

H3

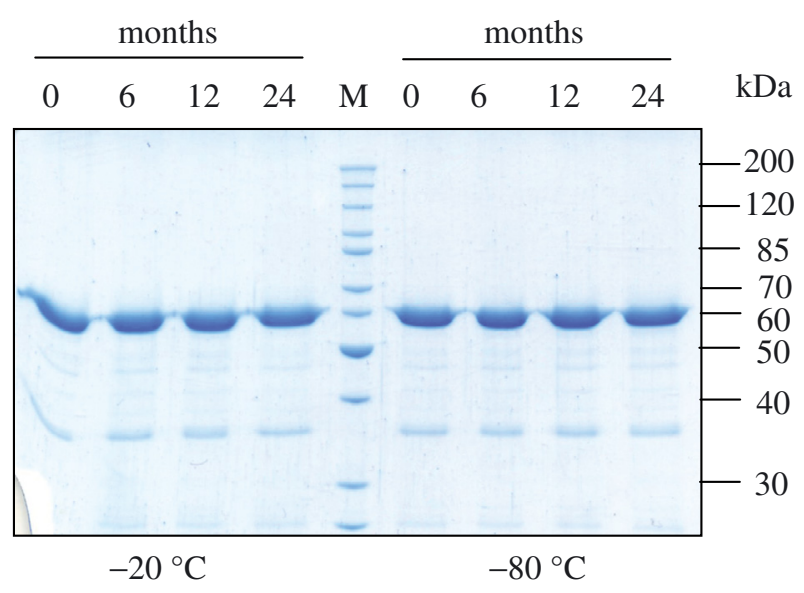

$\mathrm{H} 4$

Figure 3. SDS polyacrylamide gel electrophoresis (10\% gel) of Cry $1 \mathrm{Ab}$ batch $\mathrm{H} 3$ and batch $\mathrm{H} 4$ stored at $-80{ }^{\circ} \mathrm{C}$ and $-20{ }^{\circ} \mathrm{C}$ after $0,6,12$, and 24 months. ( $\mathrm{M}=$ PageRuler $^{\mathrm{TM}}$ protein ladder (Fermentas) with molecular masses (kDa) given to the right.)

variation in their activity (Nguyen et al., 2004; Saeglitz et al., 2006). These batch-to-batch differences could be caused by different treatments during production of these batches and/or differences in the concentration of Cry $1 \mathrm{Ab}$ depending on the protein determination methods. Crespo et al. (2008) noted that different protein batches should be produced and measured with standardized methods in order to eliminate the difference in their activity. When using the same standardized production and quantification methods, bioassay of three different Cry $1 \mathrm{Ab}$ batches produced in E. coli and B. thuringiensis showed no significant difference in $\mathrm{LC}_{50}$ values (Crespo et al., 2008).

Our study indicates that the choice of the storage temperature is a crucial factor concerning the bioactivity of $\mathrm{Cry} 1 \mathrm{Ab}$ protein in long-term monitoring the susceptibility of a target insect. When using soluble protein batches, we recommend storing the Cry $1 \mathrm{Ab}$ protein at $-80{ }^{\circ} \mathrm{C}$. On the other hand, when using the same batch of Cry $1 \mathrm{Ab}$, intrinsic variations of the $\mathrm{LC}_{50} \mathrm{~s}$ by a factor of 3-5 were observed in this and in a previous study (Nguyen et al., 2004). Due to this variability of insect response from bioassay to bioassay, a beginning shift towards resistance of a target ECB population measured as change of $\mathrm{LC}_{50}$ cannot be statistically substantiated, unless the susceptibility changed by a factor of 5 to 10 . This natural variability of bioassays has also to be considered, when resistance testing is performed at a discriminative dose, e.g. at a $\mathrm{LC}_{95}$ or $\mathrm{LC}_{98}$ (Roush and Miller, 1986). Thus, initial changes in the susceptibility of an ECB population will be hardly detected. Nevertheless, the standardization of production and storage of Cry $1 \mathrm{Ab}$ protein for long-term monitoring keep the variability of bioassays to a minimum and are a prerequisite of any successful resistance monitoring scheme.

\section{MATERIALS AND METHODS}

\section{Preparation and storage of Cry1Ab protein}

E. coli XL1-Blue containing the plasmid pBD140 carrying the $c r y l A b$ gene was kindly provided by Ruud de Maagd (Wageningen, The Netherlands) (De Maagd et al., 1996). An overnight preculture was grown at $37^{\circ} \mathrm{C}$ with vigorous shaking (220 rpm) in $5 \mathrm{~mL}$ of TB medium (12 g bacto-tryptone, $24 \mathrm{~g}$ bacto-yeast extract, $4 \mathrm{~mL}$ glycerol, $2.31 \mathrm{~g} \mathrm{KH}_{2} \mathrm{PO}_{4}$, and $12.54 \mathrm{~g} \mathrm{~K}_{2} \mathrm{HPO}_{4}$ per liter) complemented with $2 \%$ glucose and ampicillin $\left(100 \mu \mathrm{g} \cdot \mathrm{mL}^{-1}\right)$. This preculture was transferred to $500 \mathrm{~mL}$ of the TB medium containing ampicillin $\left(100 \mu \mathrm{g} \cdot \mathrm{mL}^{-1}\right)$ in a $2-\mathrm{L}$ Erlenmeyer flask and grown at $28{ }^{\circ} \mathrm{C}$ with shaking $(220 \mathrm{rpm})$. After 3 days of incubation, the cells were harvested by centrifugation at $5000 \times g$ for $10 \mathrm{~min}$ at $4{ }^{\circ} \mathrm{C}$ using a SLA- 1500 rotor (Sorvall RC5B Plus), stored at $-20{ }^{\circ} \mathrm{C}$ and then purified as described in Höss et al. (2007). Briefly, inclusion bodies (IBs) were washed several times in washing buffer (Tris/ $\mathrm{HCl}, \mathrm{NaCl}$, Triton $\mathrm{X}-100$ ), then in phosphate buffer saline (PBS), and then in double-distilled water. Finally, the IBs were solubilized in $50 \mathrm{mM}$ cyclohexyl aminopropene sulfonic acid (CAPS) buffer (pH 10.5). The solubilized Cry1Ab protoxin (130 kDa) was trypsinized with L-1-tosylamido-2phenylethyl chloromethyl ketone (TPCK)-treated bovine pancreas trypsin $\left(1 \mathrm{mg} \cdot \mathrm{mL}^{-1}\right)$ in order to obtain activated Cry $1 \mathrm{Ab}$ protein $(\sim 60 \mathrm{kDa})$. The trypsinized Cry $1 \mathrm{Ab}$ protein samples were ultrafiltrated by using polyethersulfone membrane (Millipore, NMWL: 50000 ). In total, three batches of Cry $1 \mathrm{Ab}$ protein, J6B, H3, and $\mathrm{H} 4$ were produced independently. Protein batch J6B was the first produced and stored at $4{ }^{\circ} \mathrm{C}$. In order to examine the stability 
at $-20{ }^{\circ} \mathrm{C}$ and $-80{ }^{\circ} \mathrm{C}$ storage, two protein batches, $\mathrm{H} 3$ and $\mathrm{H} 4$, were produced subsequently. The full-length protoxin of batch $\mathrm{H} 3$ was treated with trypsin twice in order to obtain the trypsin-resistant core protein. Cry $1 \mathrm{Ab}$ protein batch $\mathrm{H} 4$ was produced using the optimized protocols obtained during production of batch $\mathrm{H} 3$. Each $\mathrm{Cry} 1 \mathrm{Ab}$ batch was aliquoted and stored under the conditions described in the different experiments. The samples were aliquoted to avoid multiple freezing and thawing and to prevent protein degradation. To test stability, samples were diluted to $400 \mu \mathrm{g} \cdot \mathrm{mL}^{-1}$, aliquoted $(30 \mu \mathrm{L}$ each) and stored at $4{ }^{\circ} \mathrm{C},-20{ }^{\circ} \mathrm{C}$ and $-80{ }^{\circ} \mathrm{C}$. Every six months one aliquot of different protein batches was taken out and treated with 0.25 volumes of $4 \mathrm{X}$ sample buffer containing $40 \mathrm{mM}$ Tris/HCl, $4 \mathrm{mM}$ EDTA, 8\% $(\mathrm{w} / \mathrm{v})$ SDS, $40 \%$ (w/v) glycerol, $0.004 \%$ bromophenolblue (w/v) and 0.1 volumes of $\beta$-mercaptoethanol. The mixture was heated to $100{ }^{\circ} \mathrm{C}$ for $10 \mathrm{~min}$ and stored again at $-20^{\circ} \mathrm{C}$ or $-80{ }^{\circ} \mathrm{C}$.

\section{Protein determination}

Total protein concentration of each batch was determined using Bradford dye assay (Bio-Rad Laboratories GmbH, Munich, Germany) (Bradford, 1976). Bovine serum albumin (BSA, Fraktion V, Pierce) with concentrations of $100,200,400,600,800,1000$ and $1200 \mu \mathrm{g} \cdot \mathrm{mL}^{-1}$ was used as quantification standard.

\section{SDS polyacrylamide gel electrophoresis (SDS PAGE)}

SDS PAGE was performed following the procedure of Laemmli (Laemmli, 1970). Scan of the SDS gels were analysed using ImageMaster 1D Software (Pharmacia System) to estimate the purity level of the protein.

\section{Insect bioassays}

An ECB laboratory strain was obtained from the Julius Kuehn Institute, Institute for Biological Control, Darmstadt (Germany), and has been reared at the DLR Rheinpfalz since 2005. Bioassays were performed with first-instar ECB larvae at an age of 3-24 h after hatching. A volume of $1 \mathrm{~mL}$ of artificial diet was dispersed in each well (surface area of $1.77 \pm 0.08 \mathrm{~cm}^{2}$ per well) of the bioassay tray (Bio-ba-128, Color-Dec Italy). Cry1 Ab protein was diluted in $50 \mathrm{mM}$ CAPS buffer ( $\mathrm{pH}$ 10.5) to six different concentrations and pipetted on the surface of the diet and air dried. The concentrations of Cry $1 \mathrm{Ab}$ protein applied in the bioassay depended on the different batches, but generally ranged between 3-1000 ng. $\mathrm{cm}^{-2}$.
For each dilution, 16 larvae were assayed individually in wells. In untreated controls, 32 larvae were exposed to $50 \mathrm{mM}$ CAPS buffer ( $\mathrm{pH} 10.5$ ) instead of Cry1 Ab protein. Each bioassay was conducted at $22{ }^{\circ} \mathrm{C}$ and the mortality was assessed after 7 days. The assays were independently repeated 3-5 times.

Bioactivity was measured during 16 weeks for batch J6B stored at $4{ }^{\circ} \mathrm{C}$ and approximately every half year for batches $\mathrm{H} 3$ and $\mathrm{H} 4$ stored at $-20{ }^{\circ} \mathrm{C}$ and $-80{ }^{\circ} \mathrm{C}$, respectively. The detailed period between different bioassays is described in the results.

\section{Statistical analysis}

After correction for control mortality (Abbott, 1925), probit analysis implemented in SAS (SAS Institute, version 9.1.3, 2007) was applied to estimate the median lethal concentrations $\left(\mathrm{LC}_{50}\right)$ and the slopes of the concentration-mortality lines. Significance testing of the $\mathrm{LC}_{50}$ was done by pairwise comparisons using $95 \%$ fiducial limits (FLs) $(\alpha \leqslant 0.05)$ (Smith, 1997). Parallelism of slopes of two lines was also tested (Unkelbach and Wolf, 1985).

\section{ACKNOWLEDGEMENTS}

We are grateful to Britta Wahl-Ermel, Pascal Schlosser and Andreas Schäffer for technical assistance, Angelika Wilhelmy and Ute Poh for insect rearing, Manfred Jutzi for the statistical analysis, and Dr. Yongjie Wang and Karolin Eberle for helpful comments on the manuscript. This research was supported by the Federal Ministry for Education and Research of Germany (BMBF), grant 0313279E.

Received January 9, 2009; accepted May 28, 2009.

\section{REFERENCES}

Abbott WS (1925) A method of computing the effectiveness of an insecticide. J. Econ. Entomol. 18: 266-267

Bosch D, Visser B, Stiekema WJ (1994) Analysis of nonactive engineered Bacillus thuringiensis crystal proteins. FEMS Microbiol. Lett. 118: 129-134

Bradford M (1976) A rapid and sensitive method for the quantitation of microgram quantities of protein utilizing the principle of protein dye-binding. Anal. Biochem. 72: 248-254

Brookes G, Barfoot P (2008) GM crops: global socioeconomic and environmental impacts 1996-2006. PG Economics Ltd, UK, 20 p

Chaufaux J, Segui M, Swanson JJ, Bourguet D, Siegfried BD (2001) Chronic exposure of the European corn borer (Lepidoptera: Crambidae) to Cry1Ab Bacillus thuringiensis protein. J. Econ. Entomol. 94: 1564-1570 
Crespo ALB, Spencer AT, Nelk E, Pusztai-Carey M, Moar JW, Siegfried BD (2008) Comparison and validation of methods to quantify Cry1Ab protein from Bacillus thuringiensis for standardization of insect bioassays. Appl. Environ. Microbiol. 74: 130-135

De Maagd RA, Kwa MSG, Van der Klei H, Yamamoto T, Schipper B, Vlak JM, Stiekema WJ, Bosch D (1996) Domain III substitution in Bacillus thuringiensis DeltaEndotoxin Cry1A(b) results in superior toxicity for Spodoptera exigua and altered membrane protein recognition. Appl. Environ. Microbiol. 65: 1537-1543

EPA (1998) The Environmental Protection Agency's White Paper on Bt Plant-pesticide resistance management. US Environmental Protection Agency, Washington, DC, USA

Farinós GP, de la Poza M, Hernández-Crespo P, Ortego F, Castañera P (2004) Resistance monitoring of field populations of the corn borers Sesamia nonagrioides and Ostrinia nubilalis after 5 years of $\mathrm{Bt}$ maize cultivation in Spain. Entomol. Exp. Appl. 110: 23-30

Gonzáles-Núñez M, Otergo F, Castañera P (2000) Susceptibility of Spanish populations of the corn borers Sesamia nonagrioides (Lepidoptara: Noctuidae) and Ostrinia nubilalis (Lepidoptera: Crambidae) to a Bacillus thuringiensis endoprotein. J. Econ. Entomol. 93: 459-463

Gould F (1998) Sustainability of transgenic insecticidal cultivars: Intergrating pest genetics and ecology. Annu. Rev. Entomol. 43: 701-726

Höfte H, de Greve H, Seurinck J, Jansens S, Mahillon J, Ampe C, Vandekerckhove J, Vanderbruggen $\mathbf{H}$, van Montagu M, Zabeau M, Vaek M (1986) Structural and functional analysis of a cloned delta endotoxin of Bacillus thuringiensis berliner 1715. Eur. J. Biochem. 161: 273-280

Höss S, Arndt M, Baumgarte S, Tebbe CC, Nguyen TH, Jehle JA (2007) Effect of transgenic corn and Cry1Ab protein on the nematode, Caenorhabditis elegans. Ecotox. Environ. Saf. 70: 334-340

Huang F, Higgins RA, Buschman LL (1997) Baseline susceptibility to Bacillus thuringiensis subsp. kurstaki under selection pressure in European corn borer (Lepidoptera: Pyralidae). J. Econ. Entomol. 90: 1137-1143

Laemmli UK (1970) Cleavage of structural proteins during the assembly of the head of bacteriophage T4. Nature 227: 680-685
Marçon PCRG, Young LG, Steffey KL, Siegfried BD (1999) Baseline susceptibility of European corn borer (Lepidoptera: Crambidae) to Bacillus thuringiensis proteins. J. Econ. Entomol. 92: 279-285

Marçon PCRG, Siegfried BD, Spencer T, Hutchison WD (2000) Development of diagnostic concentrations for monitoring Bacillus thuringiensis resistance in European corn borer (Lepidoptera: Crambidae). J. Econ. Entomol. 93: 925930

Martens JWM, Visser B, Vlak JM, Bosch D (1995) Mapping and characterisation of the entomocidal domain of the Bacillus thuringiensis Cry1Ab protoxin. Mol. Gen. Genet. 247: 482-487

Meise T, Langenbruch GA (2007) Susceptibility of German populations of the Corn Borer Ostrinia nubilalis (Lepidoptera: Pyralidae) to a Bacillus thuringiensis endoprotein. Nachrichtenbl. Deut. Pflanzenschutzd. 59: 297-301

Nguyen TH, Meise T, Langenbruch GA, Jehle JA (2004) Production of Cry1Ab toxin in E. coli for standardisation of insect bioassays. WRPS/IOBC Bulletin 27: 125-130

Roush RT, Miller GL (1986) Considerations for design of insecticide resistance monitoring programs. J. Econ. Entomol. 79: 293-298

Saeglitz C, Bartsch D, Eber S, Gathmann A, Priesnitz KU, Schuphan I (2006) Monitoring the Cry1Ab susceptibility of European corn borer in Germany. J. Econ. Entomol. 99: 17681773

Siegfried BD, Marçon PCRG, Witkowski JF, Wright RJ, Warren GW (1995) Susceptibility of field populations of the European corn borer, Ostrinia nubilalis (Hübner) (Lepidoptera: Pyralidae), to the microbial insecticide Bacillus thuringiensis Berliner. J. Agri. Entomol. 12: 257-263

Smith RW (1997) Visual hypothesis testing with confidence intervals. In Proceedings of the Twenty-Second Annual SAS ${ }^{\circledR}$ Users Group International Conference, Cary NC ed, SAS Institute, pp 1252-1257. http://www2.sas.com/proceedings/ sugi22/STATS/PAPER270.PDF

Tabashnik BE, Gassmann AJ, Crowder DW, Carrière Y (2008) Insect resistance to Bt crops: evidence versus theory. Nat. Biotech. 26: 199-202

Unkelbach HD, Wolf T (1985) Qualitative DosisWirkungsanalyse. Gustav Fischer Verlag Stuttgart, p 45, 106 